\title{
The influence of fly ash zeolites fusion synthesis parameters on the received products
}

\author{
Natalia Czuma ${ }^{1,}$, Katarzyna Zarębska ${ }^{1}$, and Pawet Baran ${ }^{1}$ \\ ${ }^{1}$ AGH University of Science and Technology, Kraków, Poland
}

\begin{abstract}
Fly ash is one of possible raw material for the production of zeolites. Synthesis of zeolites with the use of fusion method enables the possibility of receiving materials of high yield of zeolites. This process may be used for efficient recycling of coal waste from power energy sector, which due to legislative indications shall no longer be directed into the landfills. The transformation of this waste into useful material of high application possibilities is possible. As received zeolites may be used eg. in purification of flue gases, which due to growing concern about the environment issues is needed. In the performed experiments the influence of a series of parameters was examined in correlation to received zeolitic material. Experimentally chosen proposition of the most beneficial process steps was presented.
\end{abstract}

\section{Introduction}

Polish energy sector is mainly based on the use of coal. One of by-products of the coal burning is fly ash, which due to its properties may become valuable substrate for zeolite synthesis $[1,2,3]$. The synthesis of zeolites with the use of fusion method is one of production options, distinguished by possibility of receiving high yields of zeolites in the synthesized material $[4,5]$. The zeolites obtained form a fly ash can be used in many differentiated sectors. Interesting application examples of its use are as: oil spills sorbents [6,7], additives for asphalt production [8], removal of benzene, toluene and xylene [9], ammonia ions [3] carbon dioxide $[3,10]$ or sulphur dioxide $[11,12]$.

In the experiments presented in this article the influence of changing the selected parameters of the performed synthesis in relation to received material was analyzed (implementation of ultrasound energy to the process, the extension of hydrothermal solution aging process, additional raw material and product of fusion grinding, solution aging for several months time and elimination of hydrothermal aging).

In the research the experiments were aimed at determining the influence of proposed process parameters change on the received zeolite material in relation to the type of received phases type and to the yield of synthesis.

\footnotetext{
* Corresponding author: nczuma@agh.edu.pl
} 


\section{Experimental}

With the use of fly ash, selected form one of the polish power plants, there were performed 5 fusion synthesis. The synthesis were differentiated in case of the temperature of fusion process, in each of temperatures 2-4 samples were prepared characterized by different amount of the used fly ash and alkali, the preparation of material to the process and treatment after the process, implementation of additional process step or its elimination (Table 1). As received samples were subjected to fusion process lasting 1 hour, in the muffle furnace, subsequently distillated water was added in the proportions $1 \mathrm{~g}$ sample, $33 \mathrm{~g}$ liquid, than shaken for 6 hours and heated in the temperature of $90^{\circ} \mathrm{C}$ for 6 hours. Received materials were rinsed with water up to $\mathrm{pH} \sim 10$ and dried.

In Table 1 the comparison of samples were presented along with the description (in comments) of changed parameter used.

Table 1. Comparison of preformed synthesis

\begin{tabular}{|c|c|c|c|}
\hline $\begin{array}{l}\text { Process } \\
\text { identifier }\end{array}$ & $\begin{array}{l}\text { Fly ash } \\
\text { to alkali } \\
\text { ratio }\end{array}$ & $\begin{array}{l}\text { Sample } \\
\text { identifier }\end{array}$ & Comment \\
\hline \multirow[b]{2}{*}{ F650 } & 2 & F650-2 & \multirow{2}{*}{$\begin{array}{l}\text { In this experiment the amount of used during fusion alkali } \\
\text { was decreased so that the fly ash/ alkali ratio would change } \\
\text { from value } 2 \text { to } 3 \text {, the heating process after the fusion was } \\
\text { performed in the temperature } 90^{\circ} \mathrm{C} \text { for } 6 \text { hours }\end{array}$} \\
\hline & 3 & F650-3 & \\
\hline \multirow{2}{*}{ F550 } & 0,83 & $\begin{array}{c}\text { F550- } \\
0,83\end{array}$ & \multirow{2}{*}{$\begin{array}{l}\text { In this experiment the amount of used during fusion alkali } \\
\text { was increased so that the fly ash/alkali ratio would change } \\
\text { from value } 0,83 \text { to } 0,7 \text {, the heating process after the fusion } \\
\text { was performed in the temperature } 90^{\circ} \mathrm{C} \text { for } 6 \text { hours }\end{array}$} \\
\hline & 0,7 & F550-0,7 & \\
\hline \multirow{4}{*}{ F700 } & 0,83 & $\begin{array}{c}\text { F700- } \\
0,83-6 \mathrm{H}\end{array}$ & \multirow{2}{*}{$\begin{array}{l}\text { In this experiment the amount of used during fusion alkali } \\
\text { was increased so that the fly ash/alkali ratio would change } \\
\text { from value } 0,83 \text { to } 0,6 \text { the heating process after the fusion } \\
\text { was performed in the temperature } 90^{\circ} \mathrm{C} \text { for } 6 \text { hours }\end{array}$} \\
\hline & 0,6 & $\begin{array}{l}\text { F700- } \\
0,6-6 \mathrm{H}\end{array}$ & \\
\hline & 0,83 & $\begin{array}{c}\text { F700- } \\
0,83-24 \mathrm{H}\end{array}$ & \multirow{2}{*}{$\begin{array}{l}\text { In this experiment the amount of used during fusion alkali } \\
\text { was increased so that the fly ash/alkali ratio would change } \\
\text { from value } 0,83 \text { to } 0,6 \text { the heating process after the fusion } \\
\text { was performed in the temperature } 90^{\circ} \mathrm{C} \text { for } 24 \text { hours }\end{array}$} \\
\hline & 0,6 & $\begin{array}{c}\text { F700- } \\
0,6-24 \mathrm{H}\end{array}$ & \\
\hline \multirow{4}{*}{ F500 } & 1 & $\begin{array}{l}\text { F500-1- } \\
\text { UA }\end{array}$ & $\begin{array}{l}\text { In this experiment after the fusion the solution was subjected } \\
\text { to the process of ultrasound disintegration, in the following } \\
\text { step the material was rinsed with distilled water and dried }\end{array}$ \\
\hline & 1 & F500-1 & $\begin{array}{l}\text { In the sample after the fusion process, shaking for } 6 \text { hours } \\
\text { took place and heating in the temperature } 90^{\circ} \mathrm{C} \text { for } 6 \text { hours }\end{array}$ \\
\hline & 1 & $\begin{array}{l}\text { F500-1- } \\
\text { UA-G }\end{array}$ & $\begin{array}{l}\text { In this experiment additional step of ultrasound disintegration } \\
\text { was added before heating in the temperature } 90^{\circ} \mathrm{C} \text { for } 6 \text { hours }\end{array}$ \\
\hline & 1 & $\begin{array}{l}\text { F500-1- } \\
3 \mathrm{M}\end{array}$ & $\begin{array}{l}\text { In this experiment after the fusion shaking for } 6 \text { hours took } \\
\text { place, sample was left in ambient temperature for } 3 \text { months, } \\
\text { the heating step was omitted }\end{array}$ \\
\hline \multirow[t]{2}{*}{ F600 } & 1 & F600- 1 & $\begin{array}{l}\text { In this experiment after the fusion, shaking for } 6 \text { hours took } \\
\text { place, the solution was heated in the temperature } 90^{\circ} \mathrm{C} \text { for } 6 \\
\text { hours, material before fusion was mixed, after the process } \\
\text { bigger agglomerated were fragmented, no grinding took } \\
\text { place }\end{array}$ \\
\hline & 1 & $\begin{array}{l}\text { F600- } 1- \\
\text { ROZ }\end{array}$ & $\begin{array}{l}\text { The material before the process of fusion was mixed and } \\
\text { ground in mortar, after the fusion process material was also } \\
\text { ground in mortar }\end{array}$ \\
\hline
\end{tabular}


Figure 1 presents sample F650-2 removed from the furnace after the fusion process.

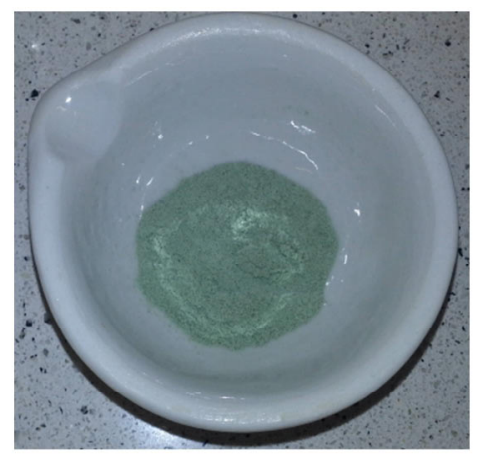

Fig. 1. Example of sample after the fusion process

After addition of distillated water to the material solutions of tint presented on Fig. 2 were received.

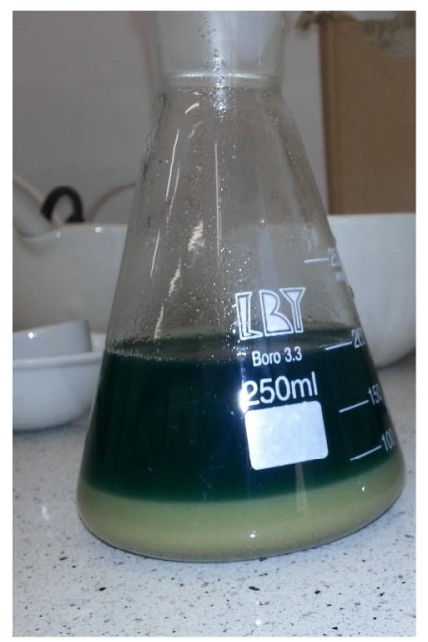

Fig. 2. Exapme of sample with destillated water added prepared for the shaking process

Solutions shaking and increased temperature lead to colour change to brownish yellow. In the final stage while the process of filtration took place the solution was practically colourless. It is suspected that the colour change is related to the oxidation state of chrome compounds present in the solution.

\section{Results}

As a result of performed synthesis material, analized with the use of XRD method in order to define the outcome of process, was recieved. 
Table 2. Comparison of synthesis results in relation to the type of zeolites recieved

\begin{tabular}{|c|c|c|c|}
\hline Process identifier & Fly ash to alkali ratio & Sample identifier & Zeolite type \\
\hline \multirow{2}{*}{ F650 } & 2 & F650-2 & $\mathrm{X}, \mathrm{A}$ \\
\hline & 3 & F650-3 & sodalite \\
\hline \multirow{2}{*}{ F550 } & 0,83 & F550-0,83 & $\mathrm{X}, \mathrm{A}$ \\
\hline & 0,7 & F550-0,7 & $\mathrm{X}, \mathrm{A}$ \\
\hline \multirow{4}{*}{ F700 } & 0,83 & F700-0,83-6H & $\mathrm{X}, \mathrm{A}$ \\
\hline & 0,6 & F700-0,6-6H & $\mathrm{X}, \mathrm{A}$ \\
\hline & 0,83 & F700-0,83-24H & sodalite \\
\hline & 0,6 & F700-0,6-24H & sodalite \\
\hline \multirow{4}{*}{ F500 } & 1 & F500-1-UA & no zeolite \\
\hline & 1 & F500-1 & $\mathrm{X}$ \\
\hline & 1 & F500-1-UA-G & $\mathrm{X}, \mathrm{P}$, sodalite \\
\hline & 1 & F500-1-3M & no zeolite \\
\hline \multirow[t]{2}{*}{ F600 } & 1 & F600- 1 & $\mathrm{X}, \mathrm{A}$, sodalite \\
\hline & 1 & F600- 1-ROZ & $\mathrm{X}, \mathrm{A}$, sodalite \\
\hline
\end{tabular}

Figures 3-7 represent the comparison of results of XRD analysis on the synthesized samples, diffractograms were presented in series in which results were analyzed.

\subsection{Data analysis for series of samples F650}

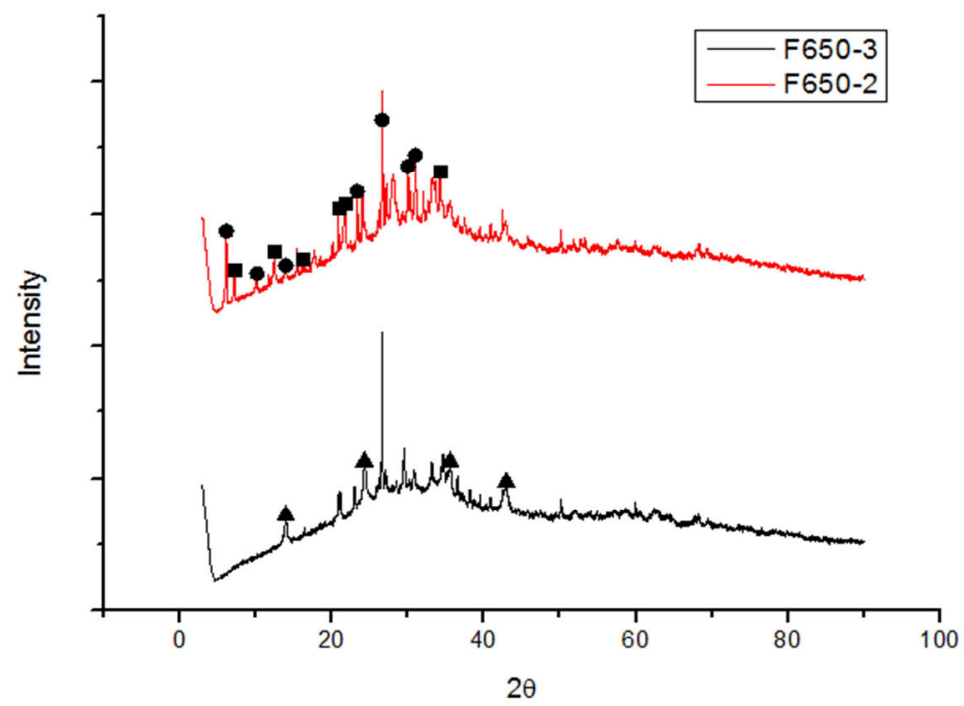

Fig. 3. Diffractograms comparison for the samples syntehsised in the fusion method series identified as F650, zeolite phases symbols: •-zeolite X, $\boldsymbol{\square}$-zeolite A, $\boldsymbol{\Delta}_{\text {-sodalite }}$

In the fusion method experiment $\left(\mathrm{F} 650^{\circ} \mathrm{C}\right)$ the decrease of alkali amount influence on the synthesis product was tested. In preliminary experiments [11] it was fund that the use of fly ash to alkali ratio of value 2 in most cases did not result in obtaining zeolite as a product. The only case of zeolite crystallization in this fly ash/alkali ratio was the one performed in the temperature $650^{\circ} \mathrm{C}$, which was the criteria of selecting this temperature as a synthesis parameter for testing increase of fly ash/alkali ratio up to value 3 . In the preformed 
experiment in comparison to other synthesis the hydrothermal reaction time was also increased to 24 hours (which was directed by receiving zeolite products in this time frames with fly ash/alkali ratio 2).

As a result of this way planned experiment, the reflections characteristic for zeolites $\mathrm{X}$ and A were obtained for fly ash/alkali ratio 2, while for fly ash/alkali ratio 3 the presence of sodalite was confirmed. Results of performed experiments indicate that it is possible to obtain zeolites of higher potential of application with the use of fly ash/alkali ratio 2 . Related research [11] performed with the use of fusion method indicated that the use of higher fly ash/alkali ratio is not efficient in relation to zeolite crystallization.

\subsection{Data analysis for series of samples F550}

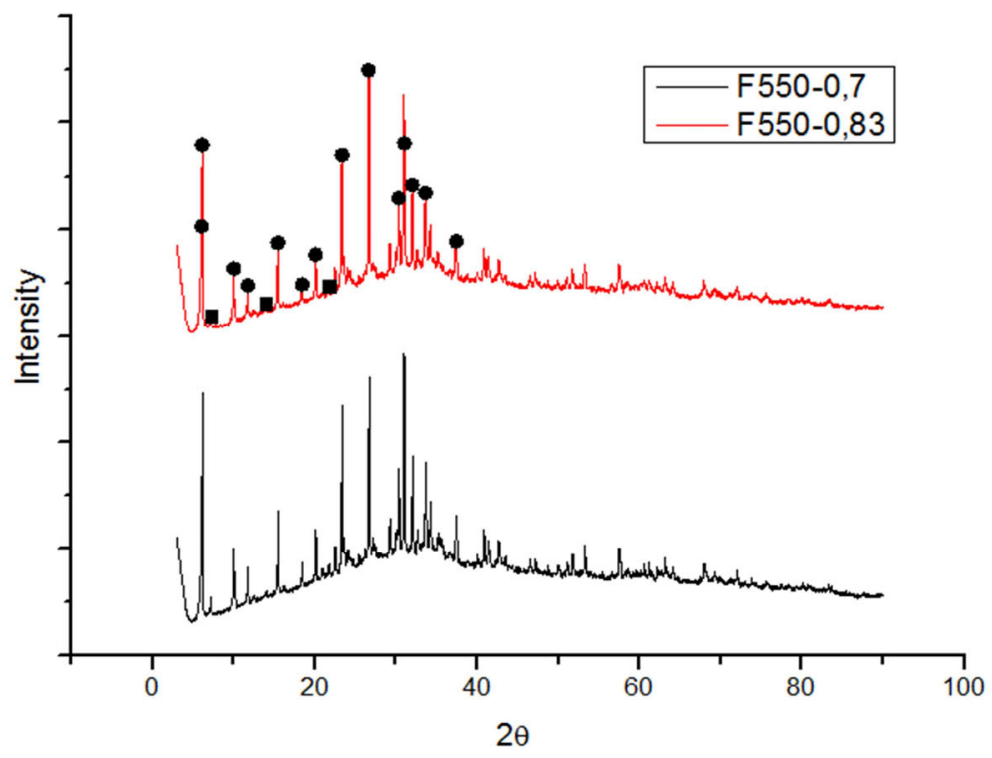

Fig. 4. Diffractograms comparison for the samples syntehsised in the fusion method series identified as F550, zeolite phases symbols: •-zeolite X, $\mathbf{\square}$-zeolite A

In the experiment performed in the temperature $550^{\circ} \mathrm{C}$ it was tested how does the change in fly ash/alkali ratio will influence the synthesis product. In the previous experiments [11], in analogical conditions the synthesis was performed with the use of fly ash/alkali ratio 2, 1, 0.83 . The most efficient outcome was found for fly ash/alkali ratio 0,83 . Based on recieved results it is objective to find out wheather the change of proportion to value 0,7 (the value selected within the range $0,83-0,6$ according to compartision options with other experimental data) will significantly affect the process and what will be the trend for observed change.

During the comparison analysis of samples diffractograms F550-0,83 and F550-0,7, the same zeolite phases were observed. However, it is worth noticing that, zeolite A presence is negligible and will not be taken into consideration. Comapring the area under the most intensive reflections characteristic for appropriate zeolite phase, it was found that F550-0,7 sampe had slightly lower efficiency in case of zeolite formation than F550-0,83 (less than $10 \%$ ). This experiemnt was to verify the previous ones and indicated that the efficiency in the research is increasing in case of used fly ash/alkali ratio as follows: $2<1<0.7<0.83$. 


\subsection{Data analysis for series of samples F700}

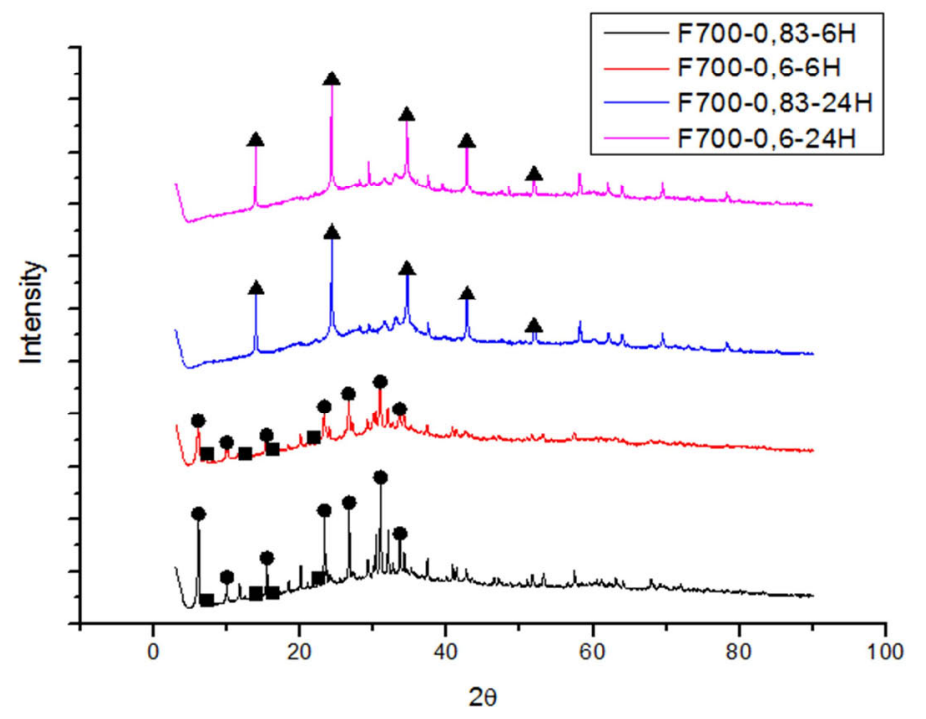

Fig. 5. Diffractograms comparison for the samples syntehsised in the fusion method series identified as F700, zeolite phases symbols: •-zeolite X, $\boldsymbol{\square}$-zeolite A, $\boldsymbol{\Lambda}_{\text {-sodalite }}$

Accoring to the received results connected with the lower efficiency with the use of lower amount of alkali, it was decided to test the influence of increasing amount of alkali added in the fusion process in the temperature of $700^{\circ} \mathrm{C}$ so that the fly ash/alkali ratio is 0,6 . The data was analysed in series by two samples synthesised in hydrotermal reaction after the fusion process which was accordingly 6 and 24 hours.

The data analysis was devided into two parts: in the first part the analysis od fly ash/alkali ratio decrease for values 0,83 to 0,6 was investigated for the hydrotermal process after the fusion, equal 6 hours. It was found that the amount of cristalizing zeolite $\mathrm{X}$ with the use of decreasing fly ash/alkali ratio is decreasing. It is worth noticing that in the same sample the amount of zeolite A was higher. The statement, pointing out that in given conditions fly ash/alkali ratio was more favourable for the synthesis of zeolite A, seems to be justified. In the second part outcome of analysis of samples for which the hydrotermal process after the fusion was 24 hours was presented. In this case it was found that fly ash/base ratio decrease lead to slight decrease of the amount of sodalite in comparison to ratio 0,83 . 


\subsection{Data analysis for series of samples F500}

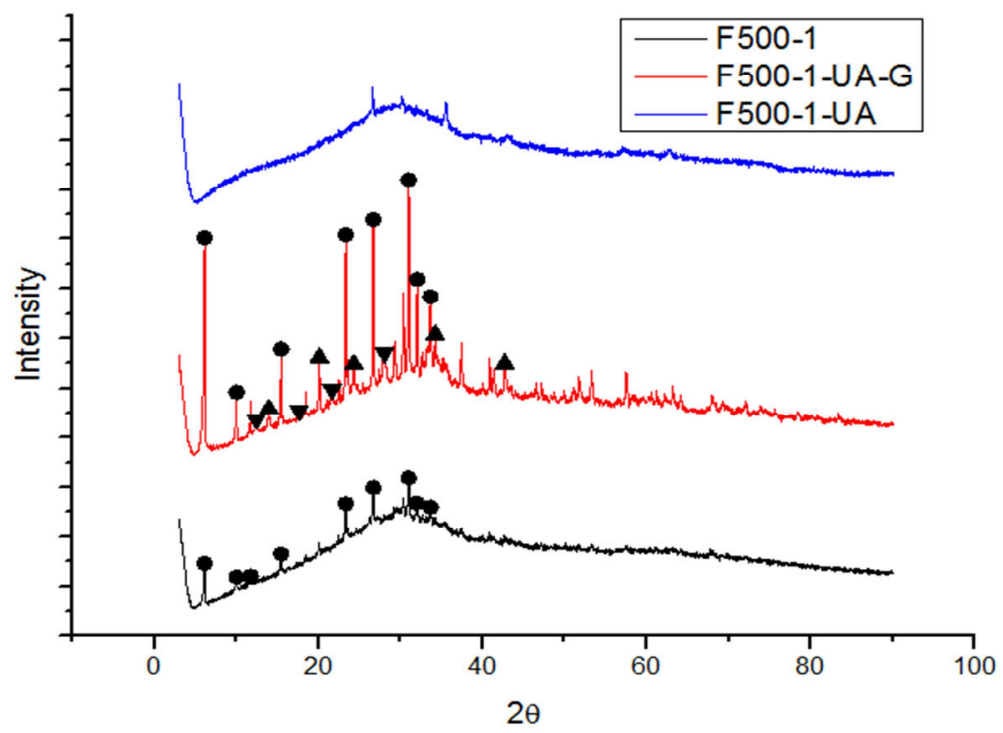

Fig. 6. Diffractograms comparison for the samples syntehsised in the fusion method series identified as

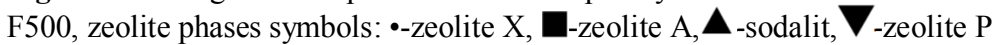

In the proposed experiments the influence of the use of ultrasonic homogenizer after the fusion process was tested in relation to zeolite phases obtained. It was decided to verify wheather very precisely disintegrated fly ash particles will positively influence the process. Four synthesis were proposed and tested: the basic one (F500-1) - material after the fusion process was dissolved in water, shaken for 6 hours and was subjected to heating in temperature $90^{\circ} \mathrm{C}$ for the period of 6 hours, synthesis (F500-1-UA) during which after the fusion, after the ultarsound homogenisation process (the time of homogenisation was 2 minuts), material was rinsed with distillated water and dried, and synthesis (F500-1-UA-G) during which the material was homogenised for 2 minutes, shaken and heated in temperature $90^{\circ} \mathrm{C}$ for the period of 6 hours. Additionally one of the samples (F500-1-3M) after the fusion process, after disolution and shaking was left in beaker for period of 3 months, according to [13].

The XRD diffractograms results analysis indicated that zeolite $\mathrm{X}$ was recieved in the sample F500-1. No zeolite cristalized in F500-1-UA as well as in F500-1-3M. The most interesting results were found for sample F500-1-UA-G, the zeolite X was recieved with efficiency around three times higher than for sample F500-1, what is more the presence of zeolite P1 and sodalite was confirmed. 


\subsection{Data analysis for series of samples F600}

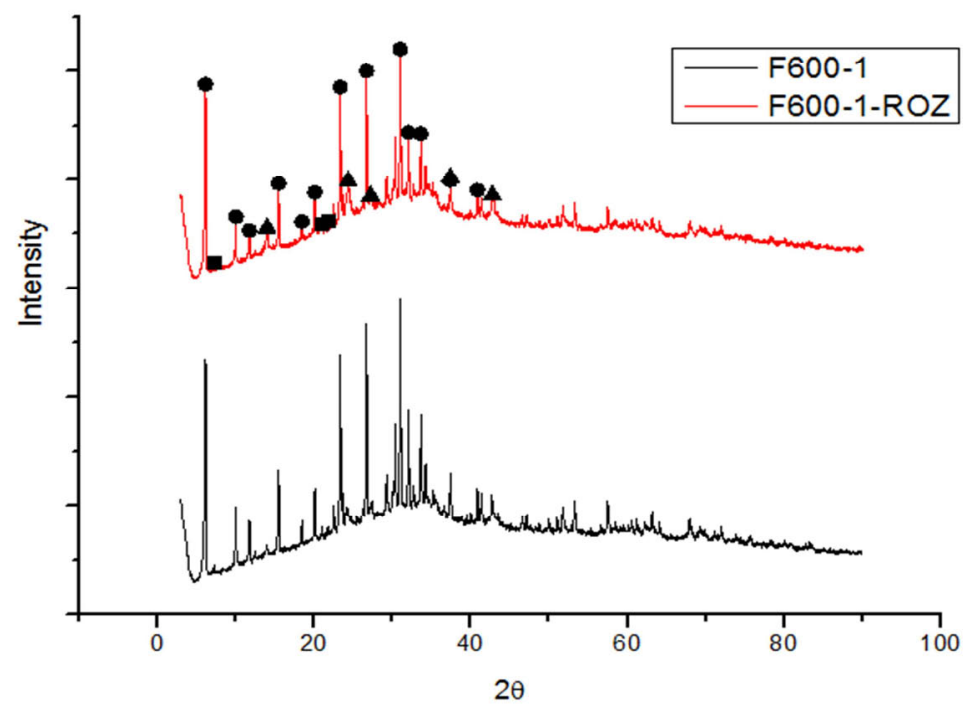

Fig. 7. Diffractograms comparison for the samples syntehsised in the fusion method series identified as F650, zeolite phases symbols: •-zeolite X, $\boldsymbol{\square}$-zeolite A, $\boldsymbol{\Lambda}$-sodalite

In the performed synthesis with the use of fusion method in temperature $600^{\circ} \mathrm{C}$, the estimation of influence of fly ash and alkali manual grinding in mortar was presented in relation to the products and its synthesis efficiency. Material was ground before and after the fusion process, the results were compared with the ones recieved with the use of ultrasound energy used for disintegration. In case of other presented in the work materials the gringing process was intentionally skipped as the raw material used (fly ash and alkali) is fine-grained itself. The prepared samples were only mixed. Similar approach was presented in case of fusion product. Although the material was dense while taking if out of ceramic crucible it was breaking up into small pieces, which were dissolving in distillated water added. In connection to literature date, stating that the material has to be additionally ground [5], the influence of the grinding process on the amount and the efficiency of zeolites produced were tested.

The diffractograms analysis of samples F600-1 and F600- 1-ROZ indicated that in both cases zeolite X, sodalite and zeolite A was present. In case of zeolite A only trace reflections were found and its presence in the following analysis will be omitted. Estimating proportions of areas under the most intense reflections, it was found that zeolite $\mathrm{X}$ represented higher share in non ground sample. This conclusion was not expected, as due to beginning assumptions smaller particles more easily will undergo fusion process, which should have effect on higher efficiencies of zeolites in products. The explanation to this unexpected result may be fact that estimated amount of sodalite in ground sample (F600-1-ROZ) is higher than in the one where there was no grinding (F600-1). Particles grinding resulted in obtaining material which was more favorable substrate for the crystallization of sodalite, using the building material needed for the crystallization of zeolite X. In this case in order to obtain zeolite $\mathrm{X}$ most probably the synthesis parameters should be changed eg. decrease of temperature or time. 


\section{Conclusions}

Based on the performed experiments it was found that, the increase of fly ash/alkali ratio up to value 3 lead to obtaining sodalite as a product-zeolite of relativelly lower application posibilities. Based on the results comparison with previously done research it can be concluded that there is a negative impact on the formation of zeolite material once the decrease of the amount of alkali used takes place.

In order to examine tha impact of using lower fly ash/alkali ratio, the experiments with the use of decreasing fly ash/alkali ratio from 0,83 to 0,7 were done. The analysis of the results indictae that slightly lower efficiencies were obtained with the use of fly ash/alkali ratio of value 0,7 . This allows to hypothesize that the ratio of lower value is less advantageous in relation to synthesis efficiency. To confirm propriety of this hypothesis the synthesis of fly ash/alkali ratio of value 0,6 was performed.

The analysis was done in two variants: with the use of hydrothermal reaction time 6 and 24 hours. It was found that for the hydrothermal reaction time 6 hours, with changed fly ash/alkali ratio form 0,83 to 0,6 the decrease of the amount of zeolite $\mathrm{X}$ is observed, at the same time the increase of zeolite A amonut was found for fly ash/alkali ratio 0,6 . For the hydrothermal reaction time 24 hours the decrease of the amount of sodalite was observed for the fly ash/base ratio 0,6 . Out of recieved results it can be concluded that the use of fly ash/base ratio 0,6 is less favourable in relation to synthesis of zeolite $\mathrm{X}$ and sodalite, at the same time fly ash/alkali ratio 0,6 is benefical for zeolite A synthesis in given synthesis conditions.

Comparing all of the tested ratios of fly ash and alkali it can be stated that the most efficient is the one of value 0,83 .

In the series of samples the analysis of the influence of implication of utrasound energy was performed. The reference sample obtained without the ultrasound energy contained zeolite $\mathrm{X}$, the use of ultrasound energy after the fusion process did not lead to zeolite crystalization (F500-1-UA). Most probably it was related to lack of time and conditions for cristals growth. The most interesting results were noted for sample for which the ultrasound disintegration was carried on before the hydrothermal aging (F500-1-UA-G). The estimated zeolite efficiency is around three times higher than in reference sample F500-1. Additionally there were present zeolite P1 phase and sodalite. In the sample F500-1-3M no zeolites were present. Analysis of this sample allows to state that despite the literature information saying that it is possible to recieve zeolite in proposed way, it was not this case. Most probably the problem might occured because of high solution evaporation rates and need for water addition. In the performed research it was also decided to check on how the disintegration of material after and before the process will influence the final product. The estimation of proportions of areas under the most intense reflections characteristic for given phases, indicates for higher amiount of zeolite $\mathrm{X}$ in non ground sample. Authors believe that grinding was more beneficail for cristalization of sodalite at the cost of zeolite $\mathrm{X}$ building material (the decrease in zeolite $\mathrm{X}$ efficiency in the samples which undergone the grinding process).

Sumarizing recieved experiments results it can be stated that the efficiency of fusion synthesis is influenced even by slight process parametras change. In this work the selection of positively influencing the zeolites of approptiate type was proposed.

The authors are grateful to AGH University of Science and Technology (Project 15.11.210.337) for its financial support of this work. 


\section{References}

1. T. Suchecki, Zeolity z popiołów lotnych. Otrzymywanie i aplikacje $w$ inż. Środowiska (Ossolineum, Wrocław, 2005)

2. I. Majchrzak-Kucęba, Mikroporowate i mezoporowate materiaty z popiołów lotnych (Wydawnictwo Politechniki Śląskiej, Częstochowa, 2011)

3. M. Franus, M. Wdowin, L. Bandura, W. Franus, Fresen. Environ. Bull. 24, 3a, 854-866 (2015)

4. S. S. Bukhari, J. Behin, H. Kazemian, S. Rohani, Fuel 140, 250-266 (2015)

5. N. Shigemoto, H. Hayashi, K. Miyaura, J. Mater. Sci. 28, 17, 4781-4786 (1993)

6. L. Bandura, M. Franus, R. Panek, A. Woszuk, W. Franus, Przem. Chem. 3, 94, 323-327 (2015)

7. L. Bandura, M. Franus, G. Józefaciuk, W. Franus, Fuel 147, 100-107 (2015)

8. A. Woszuk, W. Franus, Constr. Build. Mater. 114, 556-563 (2016)

9. L. Bandura, R. Panek, M. Rotko, W. Franus, Micropor. Mesopor. Mat. 223, 1-9 (2016)

10. Kyung-Mi Lee, Young-Min Jo, J. Mater. Cycles Waste Manag. 12, 212-219 (2010)

11. N. Czuma, K. Zarębska, P. Baran, E3S Web of Conferences 10 (2016)

12. T. T. Suchecki1, T. Wałek, M. Banasik, Pol. J. Environ. Stud. 13, 6, 723-727 (2004)

13. A. Derkowski, W. Franus, H. Waniak-Nowicka, A. Czímerová, Int. J. Miner. Process.

82, 57-68 (2007) 